\title{
EphrinB/EphB forward signaling in Müller cells causes apoptosis of retinal ganglion cells by increasing tumor necrosis factor alpha production in rat experimental glaucomatous model
}

\author{
Shu-Ting Liu', Shu-Min Zhong ${ }^{1}$, Xue-Yan Li' ${ }^{1}$ Feng Gao ${ }^{2}$, Fang Li', Meng-Lu Zhang ${ }^{1}$, Ke Zhu ${ }^{2}$, Xing-Huai Sun², \\ Xin Wang ${ }^{1}$, Yanying Miao ${ }^{1 *}$, Xiong-Li Yang ${ }^{1}$ and Zhongfeng Wang ${ }^{1 *}$
}

\begin{abstract}
It was previously shown that EphB/ephrinB reverse signaling in retinal ganglion cells (RGCS) is activated and involved in RGC apoptosis in a rat chronic ocular hypertension $(\mathrm{COH})$ model. In the present work, we first show that ephrinB/EphB forward signaling was activated in $\mathrm{COH}$ retinas, and $\mathrm{RGC}$ apoptosis in $\mathrm{COH}$ retinas was reduced by PP2, an inhibitor of ephrinB/EphB forward signaling. We further demonstrate that treatment of cultured Müller cells with ephrinB1-Fc, an EphB1 activator, or intravitreal injection of ephrinB1-Fc in normal rats induced an increase in phosphorylated EphB levels in these cells, indicating the activation of ephrinB/EphB forward signaling, similar to those in $\mathrm{COH}$ retinas. The ephrinB1-Fc treatment did not induce Müller cell gliosis, as evidenced by unchanged GFAP expression, but significantly up-regulated mRNA and protein levels of tumor necrosis factor-a (TNF-a) in Müller cells, thereby promoting RGC apoptosis. Production of TNF-a induced by the activation of ephrinB/EphB forward signaling was mediated by the NR2B subunit of NMDA receptors, which was followed by a distinct PI3K/Akt/NF-KB signaling pathway, as pharmacological interference of each step of this pathway caused a reduction of TNF-a production, thus attenuating RGC apoptosis. Functional analysis of forward and reverse signaling in such a unique system, in which ephrin and Eph exist respectively in a glial element and a neuronal element, is of theoretical importance. Moreover, our results also raise a possibility that suppression of ephrinB/EphB forward signaling may be a new strategy for ameliorating RGC apoptosis in glaucoma.
\end{abstract}

Keywords: ephrinB/EphB forward signaling, Retinal Müller cells, TNF-a, NR2B, Glaucoma

\section{Introduction}

Erythropoietin-producing hepatocyte receptor (Eph) is the largest family of transmembrane receptor tyrosine kinases $[35,51]$. Eph receptors interacting with their ligands (ephrins, Eph receptor-interacting proteins) that are expressed in the membrane of adjacent cells, initiate forward signaling acting on receptor-expressing cells and reverse signaling acting on ephrin-expressing cells $[1$,

\footnotetext{
* Correspondence: yymiao@fudan.edu.cn; zfwang@fudan.edu.cn

${ }^{1}$ Department of Neurology, Institutes of Brain Science, State Key Laboratory of Medical Neurobiology, Zhongshan Hospital, Fudan University, 131 Dongan Road, Shanghai 200032, China

Full list of author information is available at the end of the article
}

37] . Both types of signaling play crucial roles in physiological processes, such as developmental axonal guidance, cell migration, synaptic plasticity [32, 38, 48, 49]. And this system is also involved in pathological conditions, such as inflammatory neuropathic pain, hyperalgesic condition [2, 12, 35]. In experimental glaucoma models and patients with glaucoma, the expression of $\mathrm{EphB}$ and ephrin B were found to be up-regulated at the optic nerve head $(\mathrm{ONH})[17,19,20,55]$. Our recent study shows that EphB/ephrinB reverse signaling is activated in retinal ganglion cells (RGCs) in chronic ocular hypertension $(\mathrm{COH})$ rat retina, which contributes to

(c) The Author(s). 2018 Open Access This article is distributed under the terms of the Creative Commons Attribution 4.0 International License (http://creativecommons.org/licenses/by/4.0/), which permits unrestricted use, distribution, and reproduction in any medium, provided you give appropriate credit to the original author(s) and the source, provide a link to the Creative Commons license, and indicate if changes were made. The Creative Commons Public Domain Dedication waiver (http://creativecommons.org/publicdomain/zero/1.0/) applies to the data made available in this article, unless otherwise stated. 
RGC apoptosis through elevating the trafficking of $\mathrm{Ca}^{2}$ ${ }^{+}$-impermeable GluA2-containing AMPA receptors [16].

It is noteworthy that the expression of EphB1 and ephrinB2 in $\mathrm{COH}$ rats is up-regulated in Müller cells and RGCs, respectively [16]. This result suggests a possibility that there may be an activated ephrinB/EphB forward signaling from RGCs to Müller cells in $\mathrm{COH}$ retinas. In glaucoma Müller cells are reactivated, known as gliosis, which may be either protective at an early phase by enhancing the production of neurotrophic factors, or detrimental for RGCs at a later phase by promoting the release of inflammatory cytokines and other cytotoxic substances $[6,18$, 24]. We therefore explored how ephrinB/EphB forward signaling may regulate the function of Müller cells.

In the present study we first show that this forward signaling is indeed activated in Müller cells in $\mathrm{COH}$ retinas. We then examined whether and how the activation of ephrinB/EphB forward signaling in Müller cells may be involved in RGC apoptosis in $\mathrm{COH}$ retinas. We further provide evidence, suggesting that the production of pro-inflammatory cytokines tumor necrosis factor- $\alpha$ (TNF- $\alpha$ ) in Müller cells could be increased through a distinct NR2B/PI3K/Akt/NF- $\mathrm{KB}$ signaling pathway when this forward signaling was activated, thus contributing to RGC apoptosis.

\section{Materials and methods}

All experiments described in this study were carried out in accordance with the National Institutes of Health (NIH) guidelines for the Care and Use of Laboratory Animals, and were approved by the Institutes of Brain Science at Fudan University. All efforts were made to minimize the number of animals used and their suffering. Male Sprague-Dawley rats (weighing 100-150 g), obtained from SLAC Laboratory Animal Co., Ltd. (Shanghai, China), were housed on a $12 \mathrm{~h}$ light/dark schedule.

\section{Rat $\mathrm{COH}$ model}

$\mathrm{COH}$ rats were produced by injecting the micro-magnetic beads $\left(10 \mu \mathrm{l}\right.$, diameter $\approx 10 \mu \mathrm{m}$, BioMag ${ }^{\circ}$ Superparamagnetic Iron Oxide, Bangs Laboratories, Ins) into the anterior chamber of the left eyes following the procedure previously described in detail [11]. Sham-operated treatment, following a similar procedure (except for injecting the same volume of normal saline), was conventionally done on the eyes of other rats. Intraocular pressure (IOP) was measured, using a handheld digital rebound tonometer (TonoLab, Icare, Finland), in the morning to avoid possible circadian differences. The IOPs of both eyes were recorded before surgery (baseline, $0 \mathrm{~d}$ ), immediately after surgery (G0d), and on the 1st, 2nd, 3rd and 4th week after surgery (G1w, G2w, G3w and G4w, respectively).

\section{Primary retinal Müller cell culture}

Primary Müller cell cultures were prepared following the procedures described before [23]. Briefly, retinas isolated from newborn Sprague-Dawley rats (postnatal day 5) were digested with $0.25 \%$ trypsin for $15 \mathrm{~min}$ at $37{ }^{\circ} \mathrm{C}$, then mechanically dissociated using fire-polished Pasteur pipettes. The cell suspensions were cultured in the Dulbecco's modified eagle medium (DMEM/F12; Gibco, Life Technologies, Rockville, MD, USA), supplemented with $10 \%$ fetal bovine serum (FBS), $100 \mathrm{U} / \mathrm{ml}$ penicillin and $100 \mu \mathrm{g} / \mathrm{ml}$ streptomycin in a humidified $5 \% \mathrm{CO}_{2}$ circumstance at $37{ }^{\circ} \mathrm{C}$. Non-attached cells and microglia cells were removed by blowing with a fire-polished Pasteur pipette. Müller cells of the third-generation cultured for up to 21 days, were used for experiments. All experiments were performed at least in triplicate on three different batches of cultures.

\section{Treatment of cells}

EphrinB1-Fc or IgG-Fc (control) (R\&D systems, Minneapolis, MN, USA) was pre-clustered with goat anti-human IgG-Fc (Jackson ImmunoResearch Labs, Wes Grove, PA, USA) for $60 \mathrm{~min}$ at room temperature [57]. Cultured Müller cells were treated by ephrinB1-Fc (500 ng/ml) for different periods of time (1 24 h). For the inhibitory experiments, inhibitors were added to the medium 30 min before the ephrinB1-Fc treatment. The inhibitors used in this study were as follows: PP2 and RO25-6981 (Tocris, Minneapolis, MN, USA); LY294002 and PDTC (Calbiochem, San Diego, CA, USA).

\section{Intravitreal injection}

The procedure for intravitreal injection refers to our previous studies [16, 33]. EphrinB1-Fc $(0.5 \mu \mathrm{g} / \mu \mathrm{l}, 2 \mu \mathrm{l})$, XPro1595 $(50 \mu \mathrm{g} / \mu \mathrm{l}, 2 \mu \mathrm{l})$ (Xencor, Inc., Monrovia, CA, USA), 4-amino-3-(4-chlorophenyl)-1-( $t$-butyl)-1H-pyrazolo [3,4-d] pyrimidine (PP2; $100 \mu \mathrm{M}, 2 \mu \mathrm{l})$ or normal saline $(2 \mu \mathrm{l})$ was injected into the vitreous using a microinjector (Hamilton).

\section{Real-time PCR}

Total RNA was isolated from cultured Müller cells using RNAiso Plus (Takara Co., Japan). Real-time polymerase chain reaction (PCR) was performed as previously described [22]. Forward and reverse primer sequences were 5'-GAG CTG AGC GTG TGT GAC AG-3' (melting temperature (Tm): 61.9) and 5'-CGC CAG CCA ATT CTC TTT TTG C-3' (Tm: 60.0) for BDNF, 5'-GCG GTT CCT GTG AAG CGG CCG A-3' (Tm: 67.5) and 5' -TAG ATA CAT CCA CAC CGT TTA GCG G-3' (Tm: 61.9) for GDNF, 5'-CTT CAG CAT TCC CTT GAC AC-3' (Tm: 57.8) and 5'-AGC CTT CCT GCT GAG CAC ACA-3' for NGF (Tm: 61.9), 5'-AAGTTCCCAAATGG GCTC-3' (Tm: 55.0) and 5'-TCACAGAGCAATGA CTCCAAAG-3' (Tm: 58.2) for TNF- $\alpha$, 5'-ATAGCAGCT 
TTCGACAGTGAG-3' (Tm: 58.0) and 5'-GTCAACTAT GTCCCGACCATT-3' (Tm: 58.0) for IL-1 $\beta$, 5'-TTCC CTACTTCACAAGTC-3' (Tm: 52.7) and 5'-CTAG GTTTGCCGAGTAGA-3' (Tm: 55.0) for IL-6, 5'-TCA TGA AGT GTG ACG TGG ACA TC-3' (Tm: 60.2) and 5'-TGT TGC ATT TGC GGG GAC GAT G-3' (Tm: $61.9)$ for $\beta$-actin, respectively $[44,59]$. The thermal cycling conditions were $95{ }^{\circ} \mathrm{C}$ for 2 min and 40 cycles of $45 \mathrm{~s}$ at $95{ }^{\circ} \mathrm{C}, 45 \mathrm{~s}$ at $58^{\circ} \mathrm{C}$ or $60{ }^{\circ} \mathrm{C}$ and $45 \mathrm{~s}$ at $72{ }^{\circ} \mathrm{C}$. The amplification reaction was performed by using an amplification device (Eppendorf, realplex 4, GER), yielding a melting curve. The data were analyzed using $2^{-\Delta \Delta c t}$ calculation method.

\section{Western blotting}

Western blotting was conducted as previously described $[11,23,33]$. For whole-cell protein extraction, Müller cells were collected and lysed in RIPA buffer supplemented with protease and phosphatase inhibitor cocktail (Roche, supplemented, Mannheim, Germany). For nuclear and cytoplasmic protein extraction, the instructions provided for Nuclear-Cytosol Extraction kit (Applygen Technologies, Inc., Beijing, China) were followed. The concentration of proteins was measured using a standard bicinchoninic acid (BCA) assay kit (Pierce Biotechnology, Rockford, IL, USA). The extracted protein samples were separated on an $8 \%$ or $10 \%$ SDS-PAGE gel and electrotransferred to PVDF membranes (Immobilon-P, Millipore, Billerica, MA, USA). The following primary antibodies were used: monoclonal mouse anti- $\beta$-actin (A5316, 1:10000, Sigma-Aldrich, St. Louis, MO, USA), polyclonal rabbit anti-phosphoY594 EphB1/EphB2 (ab61791, 1:500, Abcam, Cambridge, MA, USA), polyclonal goat anti-EphB1 (AF542, 1:500, R\&D systems), monoclonal mouse anti-PI3K p85 $\alpha$ (sc-1637, 1:1000; Santa Cruz Biotechnology), polyclonal rabbit anti-PI3K p110 (sc-7189, 1:1000, Santa Cruz Biotechnology), polyclonal rabbit anti- Akt1/2/3 phospho Ser473 (sc-7985-R, 1:1000, Santa Cruz Biotechnology), monoclonal mouse anti-Akt1 (sc-5298, 1:1000, Santa Cruz Biotechnology), polyclonal rabbit anti-NF-kB p65 (sc-372, 1:1000, Santa Cruz Biotechnology), monoclonal mouse anti-NMDAR1 (\#556308, 1:500, BD Pharmingen, Franklin Lakes, NJ, USA), polyclonal rabbit anti-NMDA NR2B phospho Tyr1472 (\#454583, 1:500, Calbiochem), polyclonal rabbit anti-NMDAR2B (ab65783, 1:500, Abcam), monoclonal mouse anti-GFAP (G6171, 1:500, Sigma-Aldrich). The membranes were incubated with Donkey anti-mouse, rabbit or goat IgG HRP (Jackson ImmunoResearch Labs) for $1.5 \mathrm{~h}$ at room temperature, and then incubated with enhanced chemofluorescent reagent (Pierce Biotechnology). The blots were imaged with a digital imager (FluorChem E System, ProteinSimple, USA) and protein bands were quantitatively analyzed with Alpha View software (Cell Biosciences, Inc.).

\section{Immunofluorescent staining}

Immunofluorescent staining was performed following the procedure previously described [43, 70]. Briefly, cultured Müller cells, grown on cover slips, were fixed with $4 \%$ paraformaldehyde (PFA) for $20 \mathrm{~min}$. For rats with the intravitreal injection, retinas were fixed with $4 \%$ PFA for $2 \mathrm{~h}$ and dehydrated with graded sucrose solutions at $4{ }^{\circ} \mathrm{C}(2 \mathrm{~h}$ in $10 \%, 2 \mathrm{~h}$ in $20 \%$ and overnight in $30 \%$ ), and then vertically sectioned at a thickness of $14 \mu \mathrm{m}$ (Leica, Nussloch, Germany), mounted on chrome-alum-gelatin-coated slides (Fisher Scientific, Pittsburgh, PA, USA). After washing in PBS, the cultured cells or retinal sections were blocked for $1.5 \mathrm{~h}$ in $10 \%$ donkey serum, 3\% BSA and $0.1 \%$ Triton X-100, and then incubated with the following primary antibodies at $4{ }^{\circ} \mathrm{C}$ overnight: monoclonal mouse anti-GFAP (G6171; 1:400; Sigma-Aldrich), polyclonal rabbit anti-NF кB p65 (sc-372, 1:200, Santa Cruz Biotechnology). Secondary antibodies including 488-conjugated donkey anti-mouse or rabbit IgG (1:800 dilution) (Jackson ImmunoResearch Labs) were used. After washing, the cover slips or sections were mounted with anti-fade mounting medium with DAPI (Vector Laboratories, Burlingame, CA, USA) and photographed with a Leica SP2 confocal laser-scanning microscope.

\section{Enzyme-linked immunoabsorbent assay}

The concentration of TNF- $\alpha$ protein was measured by enzyme-linked immunoabsorbent assay (ELISA). The supernatants of cultured Müller cells were collected and centrifuged. For rats with the intravitreal injection, retinas were collected at day $3(3 \mathrm{~d})$ and day $7(7 \mathrm{~d})$ after the injection and lysed in RIPA buffer. ELISA were carried out with anti-rat-TNF- $\alpha$ ELISA kits (R\&D Systems), following the manufacturer instructions.

\section{Assay of cell apoptosis}

To detect cell apoptosis, terminal dUTP nick end labeling (TUNEL) assay $[10,16]$ was performed on whole flat-mounted retinas following the manufacturer instructions (Promega, Madison, WI, USA). TUNEL positive signals were visualized with a confocal laser scanning microscope through a 10x objective (FluoView 1000, Olympus), and all these that merged well with DAPI in each retina were counted.

\section{Data analysis}

All experiments on cultured cells were performed at least in triplicate on three different batches of cultures. The detailed animal number used in each experiment was given in the "Figure legends". All data were presented as means \pm S.E.M., and analyzed using GraphPad Prism software V 6.02 (GraphPad software, Inc., La Jolla, CA, USA). One-way ANOVA with Tukey's post-hoc test (multiple comparisons) or two-way ANOVA with 
Bonferroni's multiple comparisons test were used as appropriate. Statistical results were considered significant if $P$ value is less than 0.05 .

\section{Results}

EphrinB/EphB forward signaling is activated in $\mathrm{COH}$ retinas As shown in Fig. 1, in $\mathrm{COH}$ rats the average IOPs of operated eyes (left eyes) were kept at high levels from G1w to G4w $(19.2 \pm 0.5 \mathrm{mmHg}$ to $17.2 \pm 1.1 \mathrm{mmHg}, n=6 \sim 24)$, which was significantly higher than that at $0 \mathrm{~d}(9.1$ $\pm 0.2 \mathrm{mmHg}, n=24$ ), and of those of unoperated eyes (right eyes) $(9.1 \pm 0.2 \mathrm{mmHg}$ to $9.3 \pm 0.2 \mathrm{mmHg}, \mathrm{n}=6 \sim$ 24) ( $P$ all $<0.001)$. The average IOPs of sham-operated eyes (control) was $9.1 \pm 0.2 \mathrm{mmHg}(n=18)$, which was not significantly different from the value in $\mathrm{COH}$ rats at Od $(P>0.05)$. To find out whether ephrinB/EphB forward signaling was activated in rat $\mathrm{COH}$ retinas, $\mathrm{EphB1}$ and p-EphB protein levels of retinal extracts obtained from $\mathrm{COH}$ rats were determined at different post-operational times by Western blotting. Just like reported previously [16], EphB1 protein levels were significantly increased to $145.2 \pm 10.6 \%$ of that in sham-operated group (control) ( $n$ $=5, P=0.020$ vs. control) on G1w post-operationally and then remained at this higher level throughout $\mathrm{G} 4 \mathrm{w}$ (Fig. 2a, c). Moreover, the phosphorylated EphB (p-EphB) level, which is regarded as a sign of EphB1 activation, was also increased from G1w to G3w, thus resulting in increased p-EphB/EphB ratios on G1w and G3w (Fig. 2b, d), and then returned to the control level.

The changes in both EphB1 and p-EphB in $\mathrm{COH}$ retinas may be complicated by the possible involvement of Müller cell gliosis, which is induced in $\mathrm{COH}$ retinas. To determine activation of ephrinB/EphB forward signaling did occur in Müller cells, we examined how administration of ephrinB1-Fc, an activator of EphB, change EphB

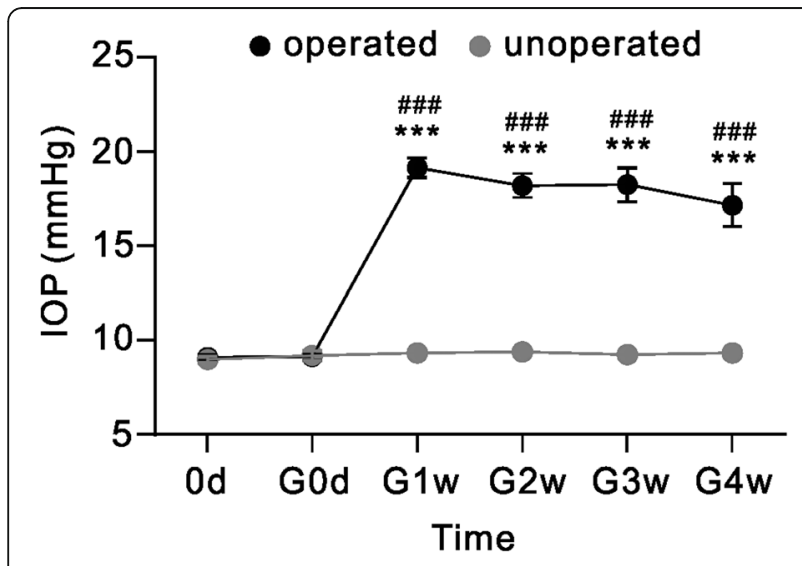

Fig. 1 Changes of IOP of both eyes in $\mathrm{COH}$ rats. IOP elevation after the injection of micro-magnetic beads in left eyes (operated eyes) as a function of time. ${ }^{* * *} P<0.001$ vs. $0 d$, and ${ }^{\# \#} P<0.001$ vs. unoperated eyes (right eyes) at the same time point and $\mathrm{p}$-EphB levels in purified Müller cells and in intact normal retinas. Fig. 2e shows the EphB1 and p-EphB protein levels when purified cultured Müller cells were treated with ephrinB1-Fc $(500 \mathrm{ng} / \mathrm{ml})$ for different periods of time. While total EphB1 protein levels showed no significant changes over a $24 \mathrm{~h}$ period, $\mathrm{p}$-EphB levels were clearly increased at $1 \mathrm{~h}$ and remained at the higher level thereafter until $6 \mathrm{~h}$ (Fig. 2e-f). The ratio of p-EphB/ EphB1 started increasing at $1 \mathrm{~h}$ following ephrinB1-Fc treatment, peaking at $3 \mathrm{~h}$, and then fluctuated around this higher level until $6 \mathrm{~h}$, which was followed by a decline to the control level (Fig. 2h).

To facilitate the analysis of roles of ephrinB/EphB forward signaling activation and possible underlying signaling pathways, we also examined effects of ephrinB1-Fc on EphB and p-EphB levels in intact normal retinas. Like in $\mathrm{COH}$ retinas, intravitreal injection of ephrinB1-Fc $(0.5 \mu \mathrm{g} / \mu \mathrm{l}, 2 \mu \mathrm{l})$ significantly increased the $\mathrm{p}$-EphB level in retinal extracts, but did not much alter the EphB1 level (Fig. 2i-l).

To test whether activated ephrinB/EphB forward signaling may induce Müller cell gliosis, GFAP protein levels were determined for cultured Müller cells treated with ephrinB1-Fc for different periods of time. As shown in Fig. 3a-b, GFAP protein expression was not significantly changed following ephrinB1-Fc treatment for different periods of time. Furthermore, expression of GFAP in Müller cells was also examined in normal retinas treated with intravitreal injection of ephrinB1-Fc and collected on $1 \mathrm{w}$ and $2 \mathrm{w}$ after the injection. GFAP labeling in the retina was hardly changed by ephrinB1-Fc injection (Fig. 3c). In both ephrinB1-Fc and normal saline-injected (control) sections GFAP labeling was strictly limited to the endfeet of Müller cells. These results suggest that activation of ephrinB/EphB forward signaling does not induce Müller cell gliosis.

\section{Activation of ephrinB/EphB forward signaling is involved in RGC apoptosis}

Whether activation of ephrinB/EphB forward signaling is involved in $\mathrm{RGC}$ apoptosis in $\mathrm{COH}$ retinas was addressed by monitoring changes in TUNEL-positive signals in $\mathrm{COH}$ retinas when ephrinB/EphB forward signaling was blocked by intravitreal injection of PP2, an inhibitor of src family tyrosine kinases. As shown in Fig. 4, the TUNEL signals in the $\mathrm{COH}$ retinas obtained on $\mathrm{G} 2 \mathrm{w}$ were much more than those in the control retinas. It is immediately evident by comparing Fig. 4 Ac and Aa that addition of PP2 made $3 \mathrm{~d}$ before the $\mathrm{COH}$ operation reduced TUNEL signals dramatically. Statistical comparison of the data is shown in Fig. 4b. It should be noted that PP2 only partially reduced the number of TUNEL-positive signals in $\mathrm{COH}$ retinas, suggesting that some factor(s) other than the activation of 


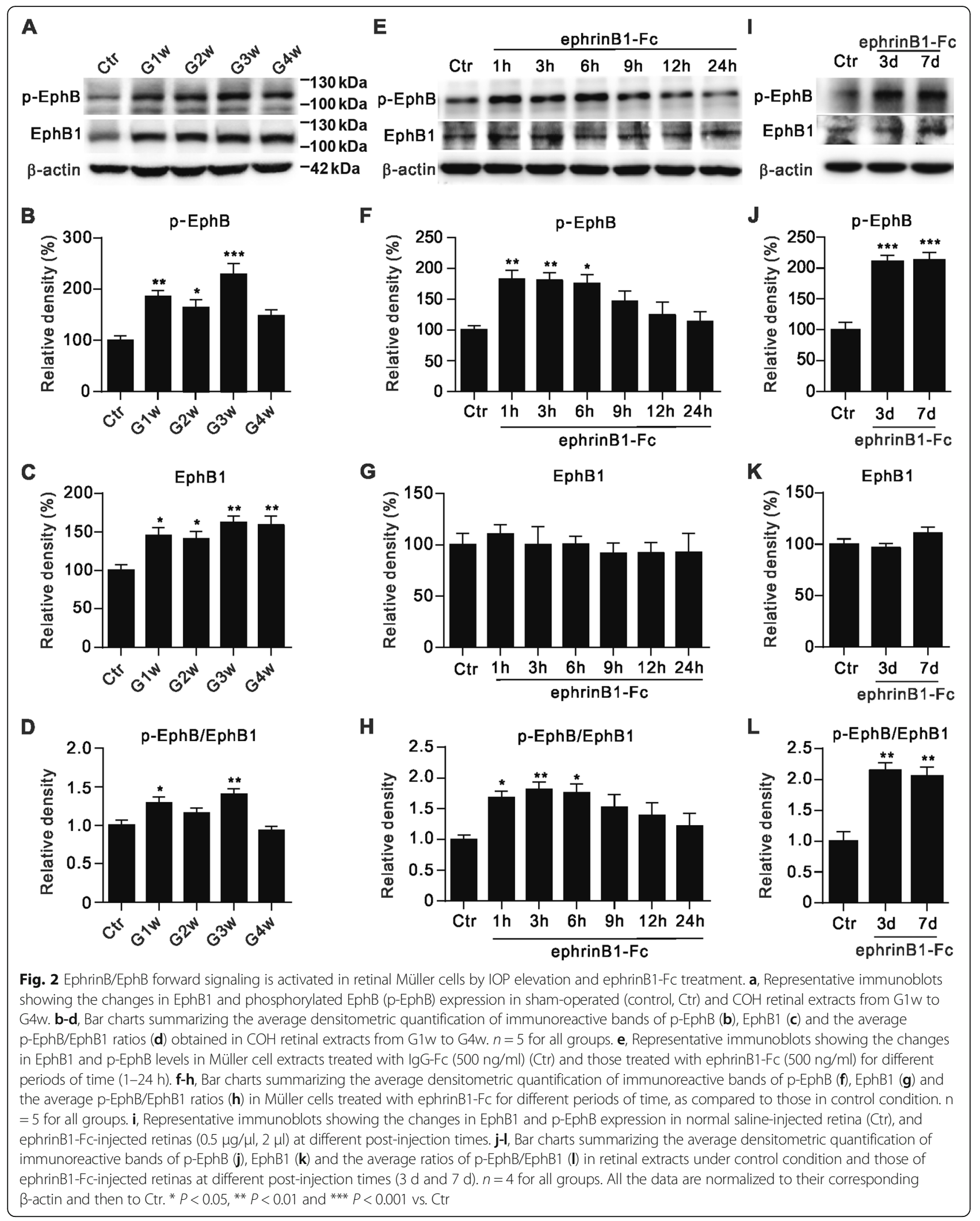




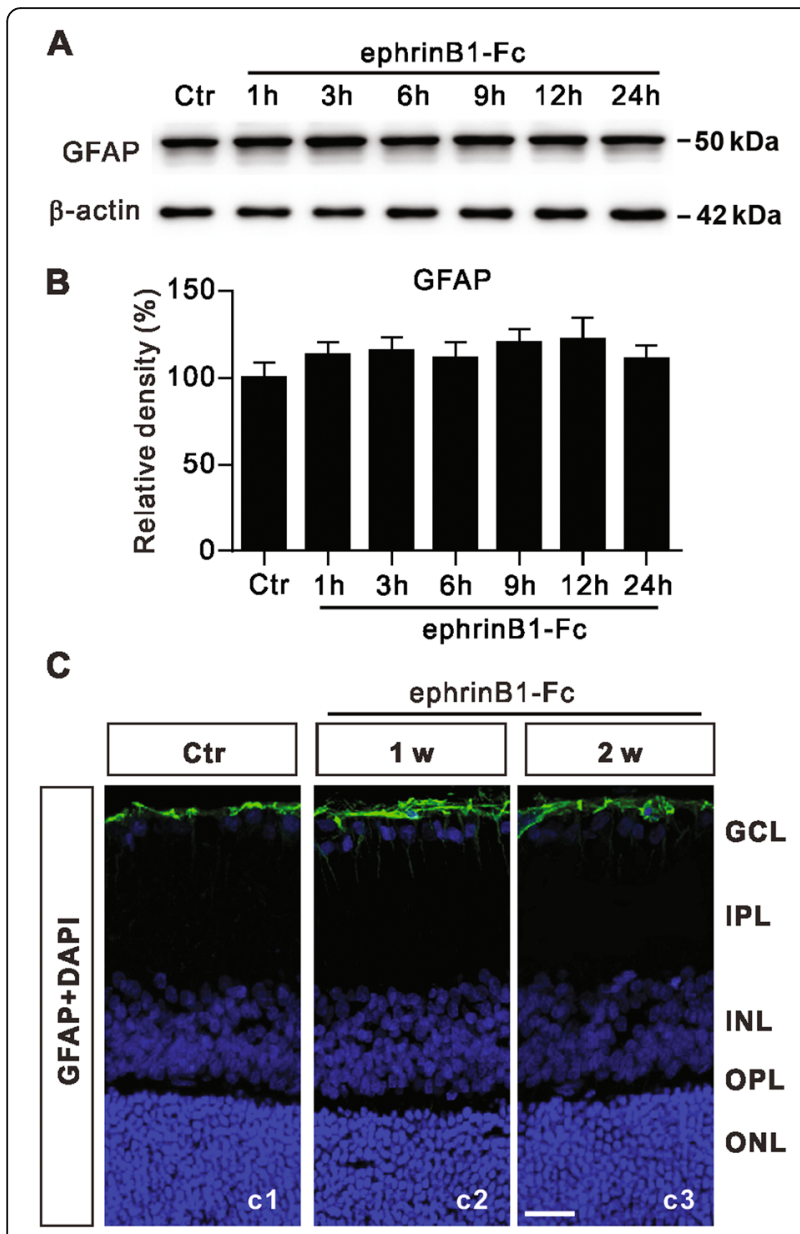

Fig. 3 Changes in GFAP protein levels in ephrinB1-Fc treated Müller cells and ephrinB1-Fc injected retinas. a, Representative immunoblots showing the changes in GFAP protein levels in Müller cell extracts treated with lgG-Fc (500 ng/ml) (Ctr) and those treated with ephrinB1FC $(500 \mathrm{ng} / \mathrm{ml})$ for different periods of time (1-24 h). $\mathbf{b}$, Bar charts summarizing the average densitometric quantification of immunoreactive bands of GFAP under the conditions as shown in A. $n=6$ for all groups. c, Immunofluorescence labeling showing GFAP expression in rat retinal vertical slices taken from normal saline-injected retina (c1) (Ctr) and ephrinB1-Fc-injected retinas on 1 and 2 weeks (c2 and c3) after the injection. Scale bar, $20 \mu \mathrm{m}$, for all the images. $\mathrm{GCL}$, ganglion cell layer; IPL, inner plexiform layer; INL, inner nuclear layer; $\mathrm{OPL}$, outer plexiform layer; ONL, outer nuclear layer

ephrinB/EphB forward signaling may contribute to RGC apoptosis in $\mathrm{COH}$ retinas.

\section{Activation of ephrinB/EphB forward signaling induces TNF-a production}

In glaucomatous retinas, activated Müller cells may be either neuroprotective or detrimental for RGCs by releasing neurotrophic factors or cytotoxic substances. Since activation of ephrinB/EphB forward signaling did not induce Müller cell gliosis, what would be the effect of activated ephrinB/EphB forward signaling on Müller cells? To address this question, we examined changes in
mRNA levels of neurotrophic factors (BDNF, GDNF and NGF) and inflammatory factors (IL-1 $\beta$, IL- 6 and TNF- $\alpha$ ) in cultured Müller cells following ephrinB1-Fc treatment, using real-time PCR technique. As shown in Fig. 5a-e, the mRNA levels of BDNF, GDNF, NGF, IL-1 $\beta$ and IL-6 all fluctuated around the control level, exhibiting no significant changes with time following ephrinB1-Fc treatment. In contrast, the mRNA level of TNF- $\alpha$ was increased at $6 \mathrm{~h}$ and $9 \mathrm{~h}$ respectively after ephrinB1-Fc treatment (Fig. 5f). It should be noted that the TNF- $\alpha$ mRNA level declined quickly and dramatically at $9 \mathrm{~h}$ after the ephrinB1-Fc treatment so that the values obtained at $12 \mathrm{~h}$ and $24 \mathrm{~h}$ were not different from the control one.

TNF- $\alpha$ protein concentrations in the culture medium of Müller cells were also evaluated as a function of time after ephrinB1-Fc treatment by ELISA assay. Almost no TNF- $\alpha$ protein could be detected in the control group (IgG-Fc) (Fig. 5g). In the ephrinB1-Fc-treated group, TNF- $\alpha$ proteins were also hardly detectable in the first $6 \mathrm{~h}$, but were steadily elevated at $9 \mathrm{~h}$ and thereafter (at $12 \mathrm{~h}$ and $24 \mathrm{~h}$ ). The effects of ephrinB1-Fc on TNF- $\alpha$ mRNA and protein levels were not seen in Müller cells pre-incubated with PP2. Figure $5 \mathrm{~h}$ shows that in these cells pretreated with PP2 $(10 \mu \mathrm{M}$ or $50 \mu \mathrm{M})$ for $30 \mathrm{~min}$ beforehand, ephrinB1-Fc no longer increased the TNF- $\alpha$ mRNA level at $6 \mathrm{~h}$. Similarly, the increase in TNF- $\alpha$ protein concentration in the culture medium of Müller cells treated with ephrinB1-Fc for $24 \mathrm{~h}$ was also blocked by pre-incubation of PP2 (Fig. 5i).

Intravitreal injections of ephrinB1-Fc also elevated TNF- $\alpha$ mRNA and protein levels in intact normal retinas. In these experiments, animals treated with normal saline constituted a control group. The TNF- $\alpha$ mRNA level was significantly increased to $384.1 \pm 74.5 \%$ of control at $3 \mathrm{~d}$. The level became lower at $7 \mathrm{~d}$, but still higher than the control level (Fig. 5j). Similarly, the protein concentration of TNF- $\alpha$ in the ephrinB1-Fc injected retinas was steadily increased to at $3 \mathrm{~d}$ and $7 \mathrm{~d}$ (Fig. 5k). These results suggest that activation of ephrinB/EphB forward signaling did induce an increase in TNF- $\alpha$ synthesis and release in Müller cells.

When ephrinB/EphB forward signaling activation-induced TNF- $\alpha$ production from Müller cells was suppressed, RGC apoptosis was largely reduced. Figure 6 shows that numerous TUNEL-positive signals were seen in the ephrinB1-Fc injected retina (Fig. 6Ab), much more than those detected in the normal saline injected control retina (Fig. 6Aa). Furthermore, intravitreal co-injection of XPro1595, a selective inhibitor of soluble TNF- $\alpha$ [3], remarkably reduced the number of TUNEL-positive signals in the ephrinB1-Fc injected retina (Fig. 6a-b), meaning a reduction of the ephrinB1-Fc induced effect. The fact that the number was still higher than the control one suggests that only part of RGC apoptosis induced by activation of 

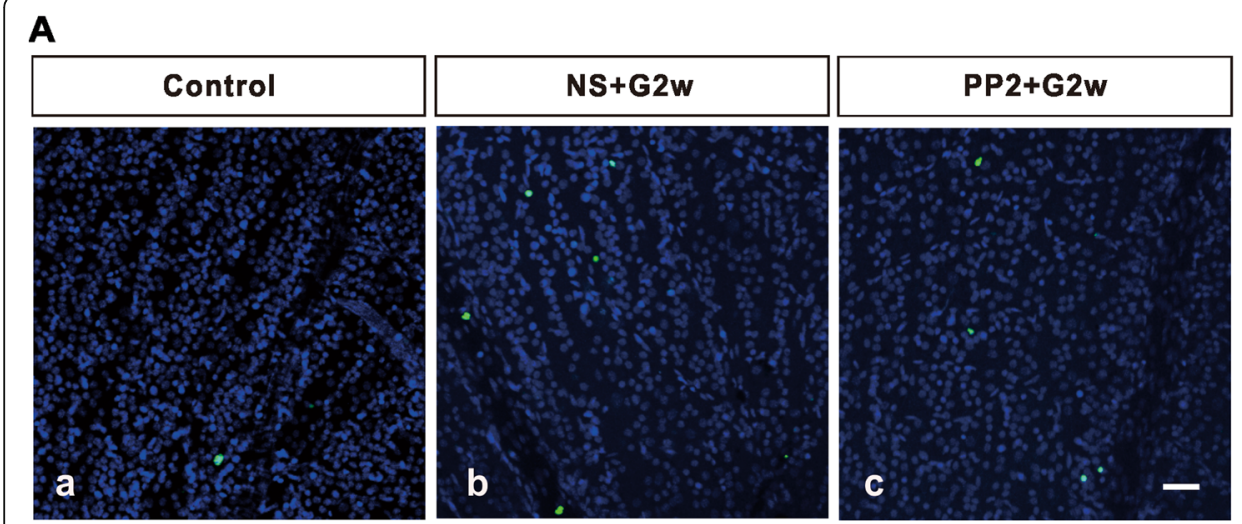

B

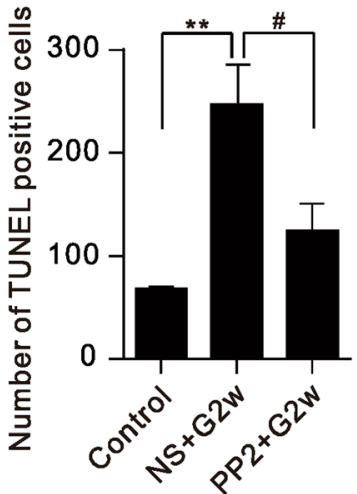

Fig. 4 Inhibition of ephrinB/EphB forward signaling reduces RGC apoptosis. a, Representative TUNEL staining images of RGC apoptosis in sham (control) (a), normal saline (NS)-injected (NS + G2w) (b), and PP2-injected (PP2 + G2w) (c) whole flat-mounted retinas on G2w in the regions at angle $0^{\circ}$. Scale bar, $50 \mu \mathrm{m}$, for all the images. $\mathbf{b}$, Bar chart showing the average numbers of TUNEL-positive cells in whole flat-mounted retinas under different conditions. $n=4 \sim 5 .{ }^{*} P<0.01$ vs. control; ${ }^{\#} P<0.05$ vs. NS + G2w group

ephrinB/EphB forward signaling may be mediated by increased production of TNF- $\alpha$ from Müller cells.

\section{NR2B/PI3K/Akt/NF-KB signaling pathway mediates TNF-a production induced by ephrinB/EphB forward signaling activation}

To understand how activated Ephrin/Eph forward signaling causes the production of TNF- $\alpha$ from Müller cells, possible involvement of NMDA receptors was examined. It was reported that in excitotoxic loss of retinal neurons in mice TNF- $\alpha$ protein production in Müller cells plays a crucial role, which was mediated through NMDA receptor-induced intracellular signaling mechanisms [40]. Moreover, the NMDA receptor antagonist memantine displays protective effects against streptozotocin treatment-induced activation of rat astrocytoma cell line by reducing TNF- $\alpha$ protein levels [54]. Since NMDA receptor subunits, such as NR1 and NR2A-D, are expressed in Müller cells $[39,53]$, we therefore tested changes in expression of NR1 and NR2B subunits in cultured Müller cells following ephrinB1-Fc treatment. These two subunits were chosen because there is evidence that the ephrinB/EphB system could directly interact with NR1 and modulate tyrosine phosphorylation of NR2B [14, 25, 56, 60]. EphrinB1-Fc treatment for different periods of time did not significantly affect protein levels of either NR1 or NR2B (Fig. 7a-c) in cultured Müller cells. However, the levels of phosphorylated NR2B at Tyr1472 site (p-NR2B) were steadily increased over time (Fig. $7 \mathrm{c}-\mathrm{d}$ ) so that the ratio $\mathrm{p}-\mathrm{NR} 2 \mathrm{~B} / \mathrm{NR} 2 \mathrm{~B}$ was increased at $1 \mathrm{~h}$, and remained around this higher level throughout $9 \mathrm{~h}$. The ratio tended to decline to the control level thereafter. This elevation of $\mathrm{p}-\mathrm{NR} 2 \mathrm{~B}$ protein was prevented by PP2 pre-incubation (Fig. 7e-f).
Moreover, the increased mRNA and protein levels of TNF- $\alpha$ in Müller cells induced by ephrinB1-Fc treatment could be abolished by $5 \mu \mathrm{M}$ RO25-6981, a specific NR2B antagonist [29]. As shown in Fig. 7g-h, when the cells were pre-incubated with RO25-6981, both mRNA and protein levels were almost unchanged. These results strongly suggest that the activation of NMDA receptors may be a key step in the signaling pathway mediating ephrinB/EphB forward signaling induced production of TNF- $\alpha$.

Phosphatidylinositol 3-kinases (PI3K) are heterodimers composed of a catalytic subunit (p110) and an adaptor/ regulatory subunit (p85). Since $\mathrm{Ca}^{2+}$ influx through NMDA receptors is known to activate PI3K [4, 9, 34], how this protein level in Müller cells was changed by ephrinB1-Fc treatment was examined. As shown in Fig. 8a-c, the protein levels of PI3K p85 subunit started increasing at $3 \mathrm{~h}$, and slightly declined at $6 \mathrm{~h}$ after ephrinB1-Fc treatment, and then returned to the control level. Similar results were obtained for PI3K p110 subunit. The elevation in both p85 and p110 was blocked by pre-incubation with RO25-6981 (Fig. 8d-f).

Akt is a downstream molecule of PI3K, and there is evidence that PI3K/Akt signaling is involved in EphB-mediated events [27, 58, 69]. Western blotting shows that the p-Akt/Akt ratio was increased at $1 \mathrm{~h}$ and $3 \mathrm{~h}$, respectively, and declined to the control level during the remaining $12 \mathrm{~h}$ (Fig. 8g-h). Again, the increased ratios were abolished by pre-incubation with PP2 (Fig. 8i-j).

We further explored whether the transcription factor nuclear factor-kappa B (NF-kB), a direct downstream molecule of activated PI3K/Akt signaling $[15,66]$, may be involved. In normal cultured Müller cells, faint NF-kB p65 positive fluorescence signals were located in the cytosol, and the signals were clearly increased from $1 \mathrm{~h}$ to $9 \mathrm{~h}$ after ephrinB1-Fc treatment by immunostaining (Fig. 9a). From 


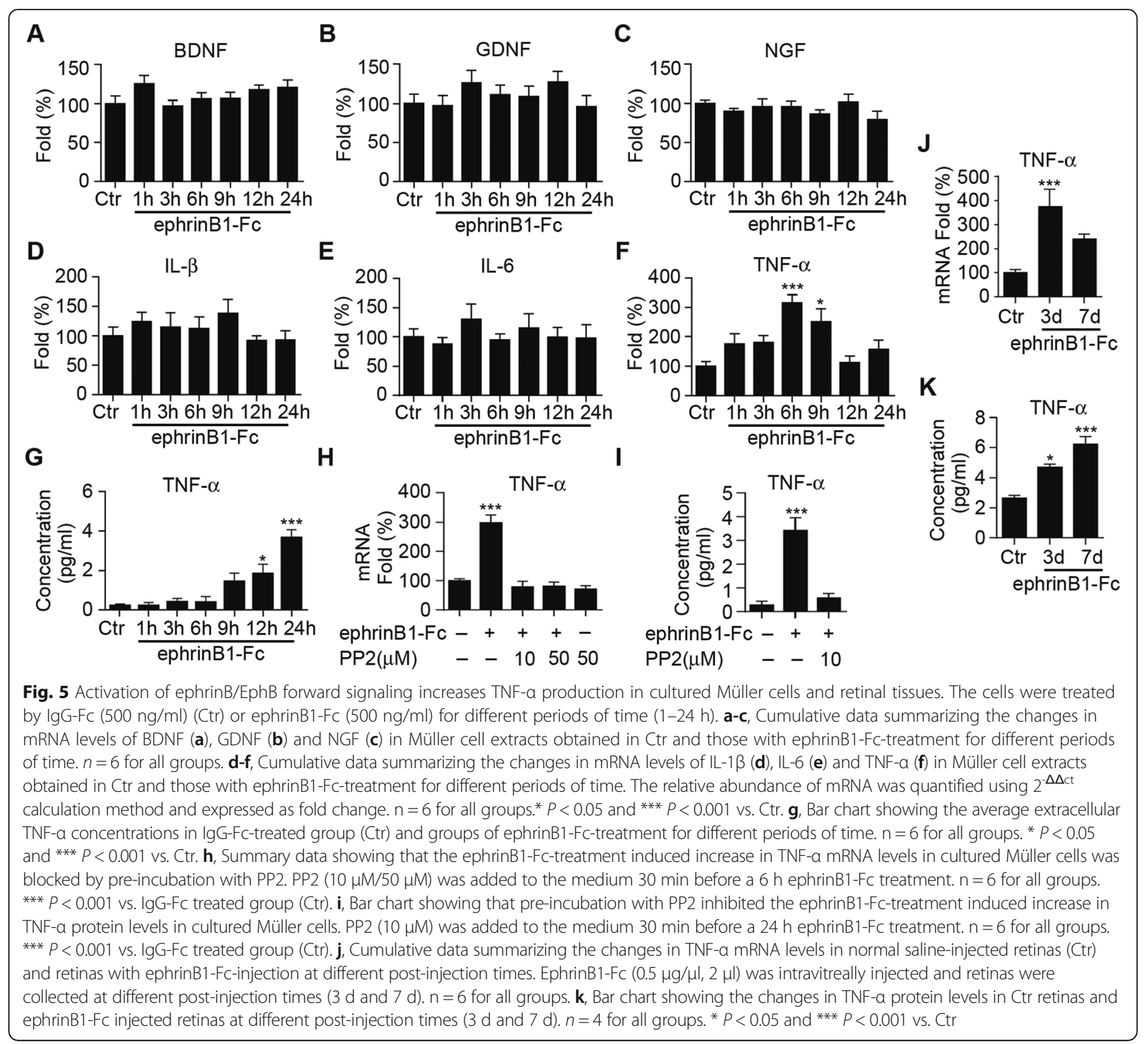

A

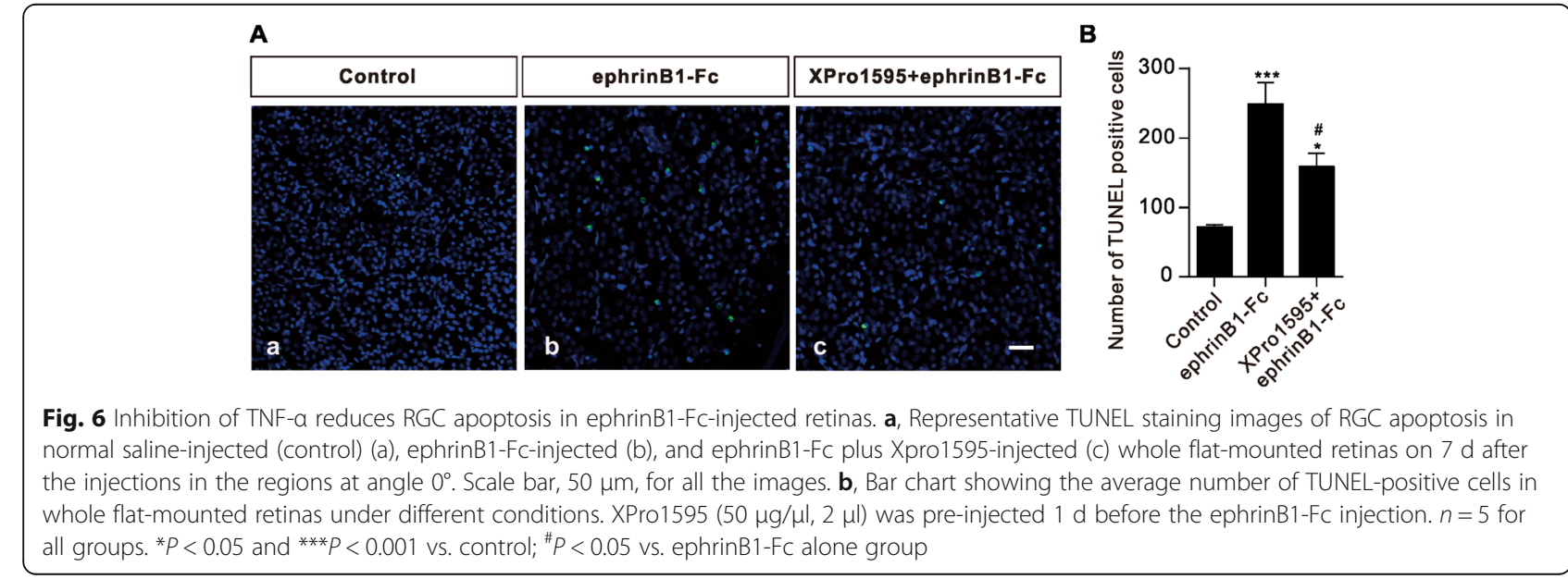

B

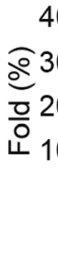




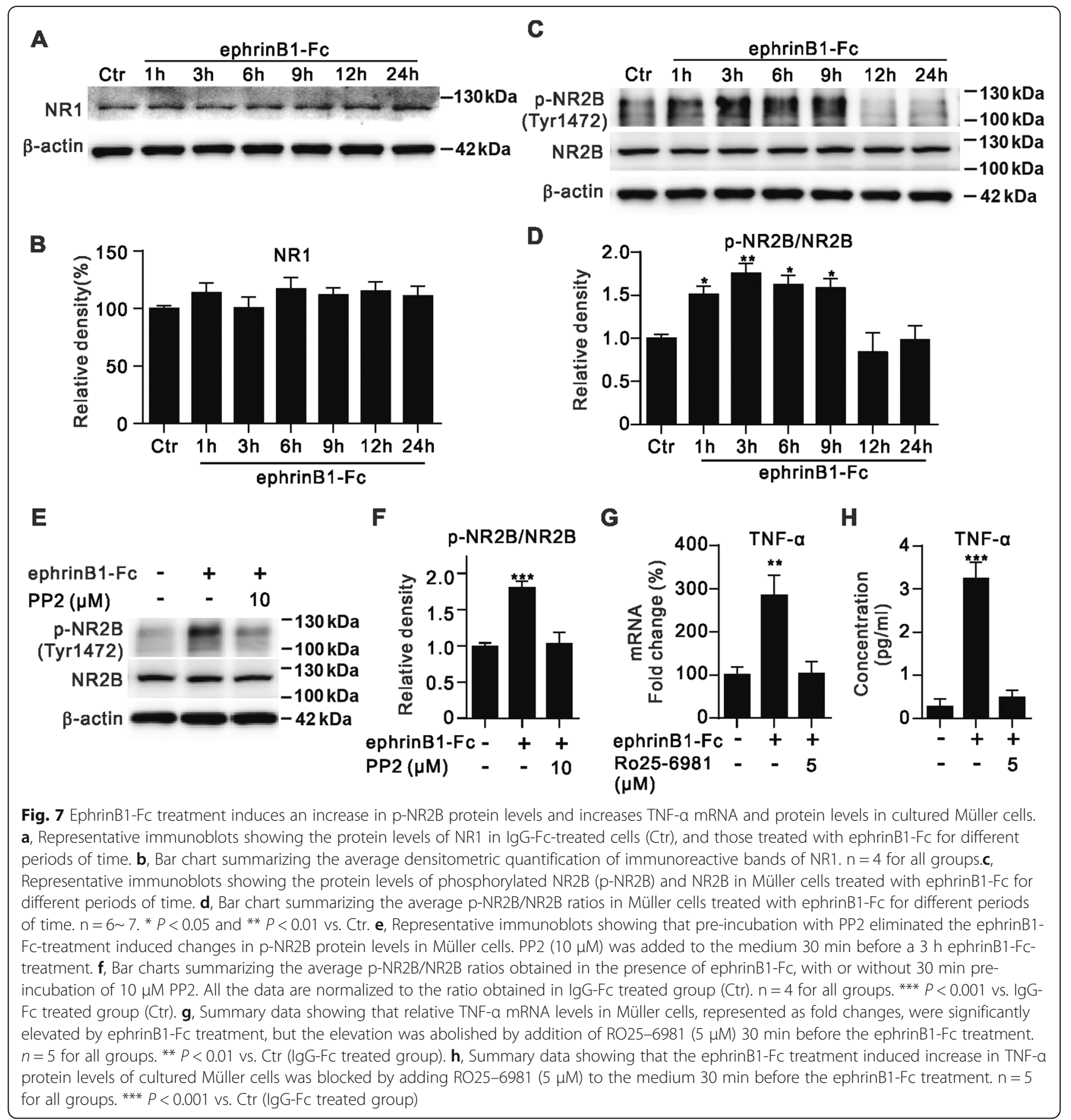

the merged images it was clear that more NF- $\mathrm{kB}$ p 65 positive signals were detected in the nucleus from $3 \mathrm{~h}$ to $9 \mathrm{~h}$, suggesting a translocation from the cytosol to the nucleus. Changes in NF- $\mathrm{KB}$ p65 expression were confirmed by Western blotting (Fig. 9b-e). In the whole lysates of Müller cells, a significant increase in NF- $\mathrm{kB}$ p65 protein level was seen only at $3 \mathrm{~h}$ during a $24 \mathrm{~h}$ ephrinB1-Fc treatment. In the nucleus fraction, however, the relative density of NF- $\mathrm{KB}$ p 65 was increased at $3 \mathrm{~h}$ and remained at this higher level for at least $6 \mathrm{~h}$ before returning to the control level at $12 \mathrm{~h}$ (Fig. 9d-e). Pre-incubation with the PI3K inhibitor LY294002 prevented the elevation of NF- $\mathrm{KB}$ p65 protein levels in the nucleus fraction of cultured Müller cells induced by ephrinB1-Fc treatment for $3 \mathrm{~h}$ (Fig. 9f-g).

Pharmacological suppression of NF- $\mathrm{kB}$ may attenuate the ephrinB1-Fc-induced changes in TNF- $\alpha$ mRNA and protein levels in cultured Müller cells. When Müller cells were pre-incubated with PDTC, a selective NF- $\mathrm{kB}$ inhibitor, ephrinB1-Fc no longer induced the increase in TNF- $\alpha$ mRNA level. Similarly, PDTC completely 


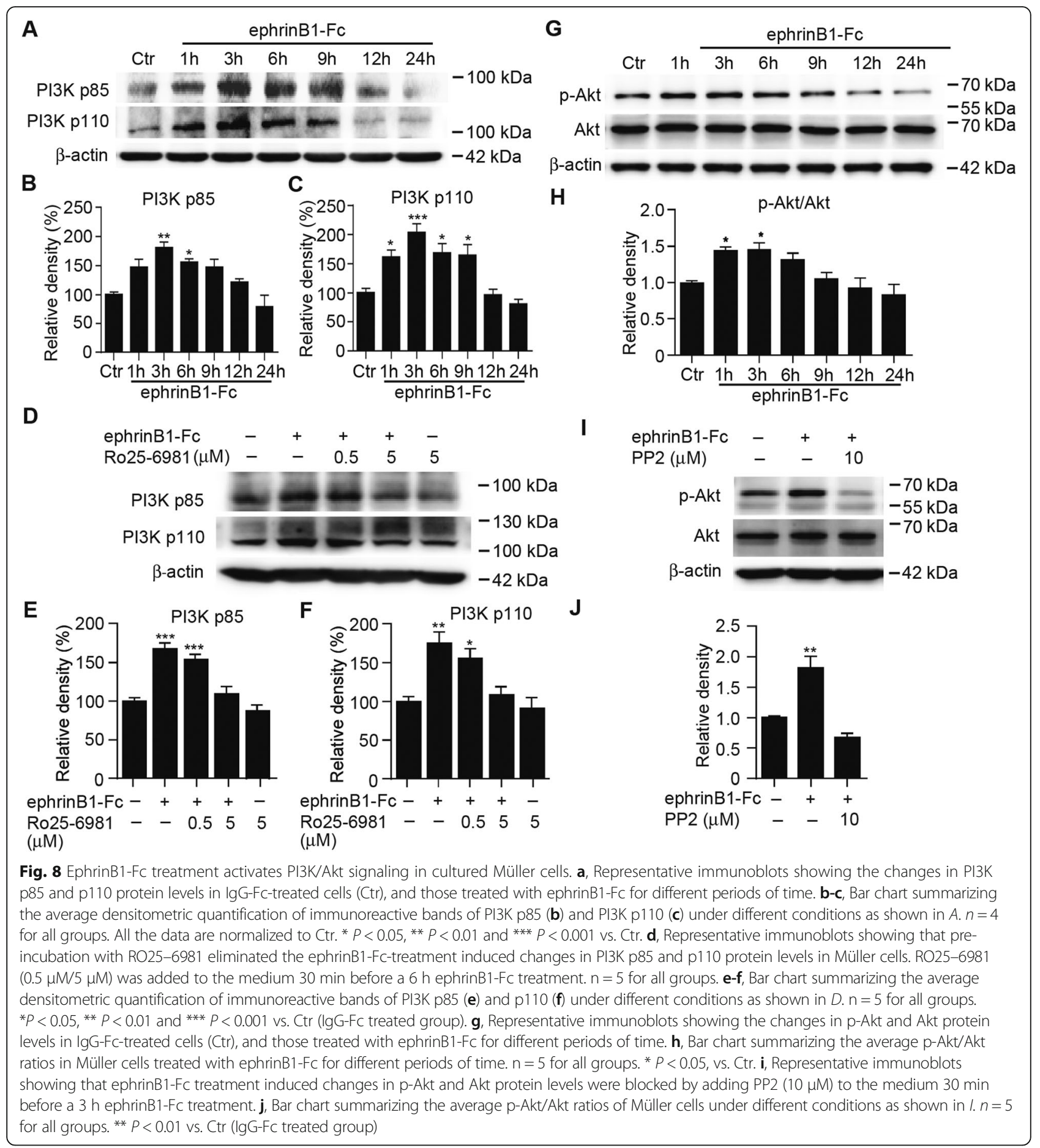

inhibited the ephrinB1-Fc treatment-induced elevation of TNF- $\alpha$ protein concentrations (Fig. 9h-i).

\section{Discussion}

Activation of ephrinB/EphB forward signaling in $\mathrm{COH}$ retinas In the present work we first showed that the $\mathrm{p}$-EphB levels in retinal extracts of both $\mathrm{COH}$ and ephrinB1-Fc injected eyes were significantly increased as determined by Western blotting (Fig. 2a, i). Because phosphorylation of EphB increases the enzymatic activity of EphB, increased p-EphB is often regarded as a sign of EphB activation. Moreover, ephrinB1-Fc treatment did increase p-EphB levels in purified cultured Müller cells. These results suggest an activation of ephrinB/EphB forward signaling between RGCs and Müller cells in $\mathrm{COH}$ retinas. It is noteworthy that EphB1 levels were increased in 


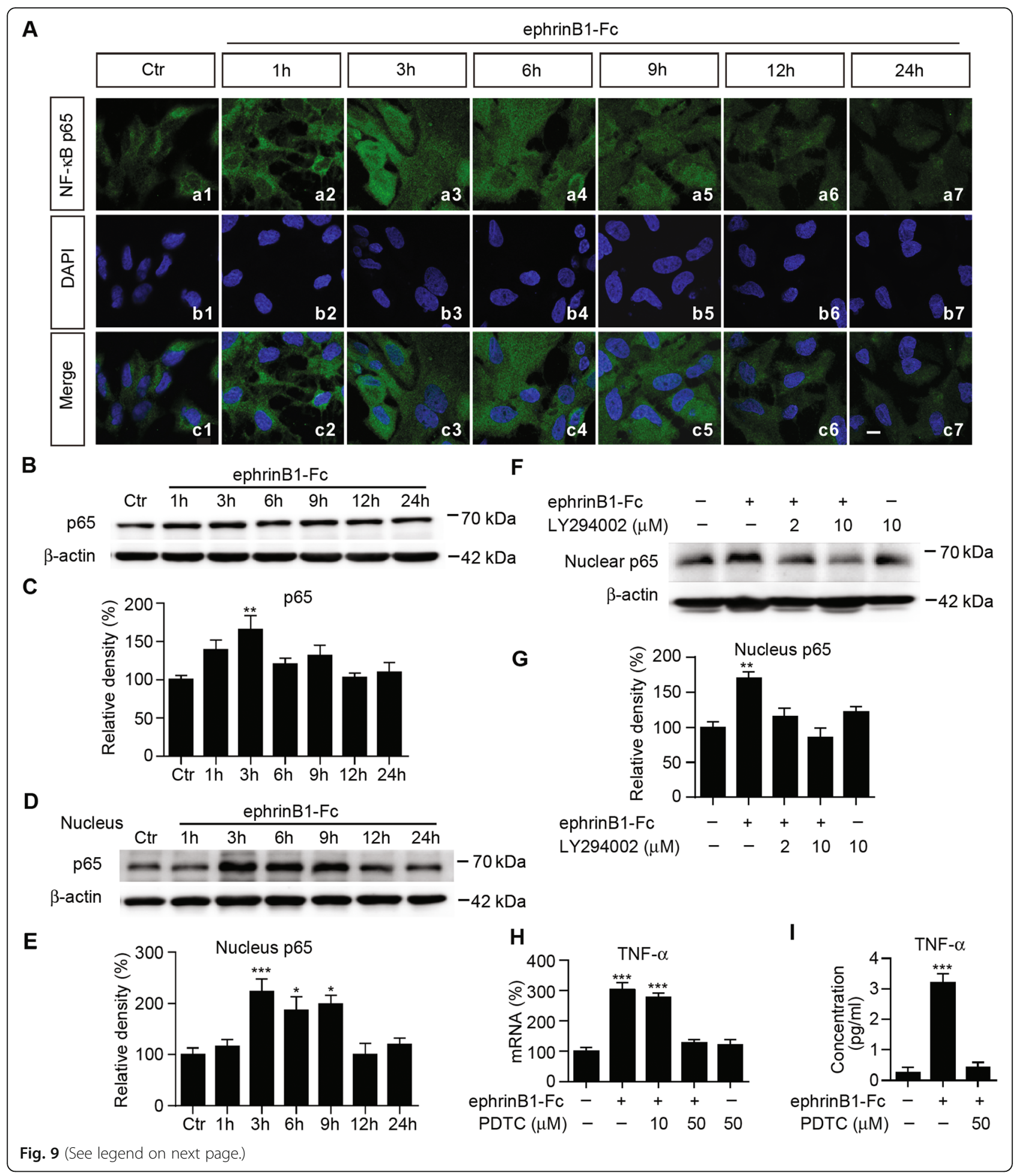


(See figure on previous page.)

Fig. 9 Activation of ephrinB/EphB forward signaling induces translocation of NF-KB p65 from the cytoplasm into the nucleus. a, Confocal laser microphotographs of cultured Müller cells, stained with the antibody against NF-KB p65 (green), showing the changes in NF-KB p65 protein expression in IgG-Fc treatment (Ctr) and ephrinB-Fc-treatment for different periods of time (a1-a7). b1-b7 are DAPI images. c1-c7 are merged images. Scale bar: $10 \mu \mathrm{m}$, for all the images. b, Representative immunoblots showing the changes in NF-KB p65 protein levels in whole cell extracts obtained from IgG-Fc-treated cells (Ctr) and those treated with ephrinB1-Fc for different periods of time. c, Bar chart summarizing the average densitometric quantification of immunoreactive bands of NF-kB p65 in Müller cells treated with ephrinB1-Fc for different periods of time. $n=5$ for all groups. ${ }^{*} P<0.01$ vs. Ctr. $\mathbf{d}$, Representative immunoblots showing the changes of NF-KB p65 in nucleus component of Müller cells treated with lgG-Fc (Ctr), and with ephrinB1-Fc for different periods of time. e, Bar chart summarizing the average densitometric quantification of immunoreactive bands of nucleus NF-KB p65 under the conditions as shown in $D . n=6$ for all groups. ${ }^{*} P<0.05$, and ${ }^{* * *} P<0.001$ vs. Ctr. f, Representative immunoblots showing the changes in NF-kB p65 protein levels in the nucleus component of Müller cells obtained in the presence of ephrinB1-Fc, with or without in the presence of LY294002. LY294002 (2 $\mu \mathrm{M} / 10 \mu \mathrm{M})$ was added to the medium 30 min before a $3 \mathrm{~h}$ ephrinB1-FC treatment. g, Bar chart summarizing the average densitometric quantification of immunoreactive bands of nucleus NF-kB p65 under the conditions as shown in $F . n=4$ for all groups. ${ }^{*} P<0.01$ vs. Ctr (lgG-Fc treated group). h, Summary data showing that pre-incubation with PDTC inhibited the ephrinB1-Fc treatment induced increase in TNF-a mRNA levels in Müller cells. PDTC (10 $\mu \mathrm{M} / 50 \mu \mathrm{M})$ was added to the medium 30 min before the ephrinB1-Fc treatment. $n=4$ for all groups. i, Summary data showing that PDTC blocked the ephrinB1-Fc treatment induced increase in TNF-a protein levels in Müller cells. PDTC $(50 \mu \mathrm{M})$ was added to the medium 30 min before the ephrinB1-Fc treatment. $n=4$ for all groups. ${ }^{* *} P<0.01$ and *** $P<0.001$ vs. Ctr (IgG-Fc treated group)

$\mathrm{COH}$ retinas, but not in EphrinB1-Fc-injected retinas. A possible explanation for this difference is that elevation of IOP may activate signaling pathways, other than ephrinB/EphB forward signaling, which induce an increase in EphB1 expression. Furthermore, we demonstrated that $\mathrm{RGC}$ apoptosis in $\mathrm{COH}$ retinas could be reduced by PP2, suggesting that activation of ephrinB/ EphB forward signaling may be an important factor responsible for RGC apoptosis in glaucoma. It should be emphasized that the activation of ephrinB/EphB forward signaling did not induce Müller cell gliosis, as suggested by the unchanged GFAP expression and morphology of Müller cells following ephrinB1-Fc treatment. It means that the increase in $\mathrm{p}$-EphB level may be not related to Müller cell gliosis occurring in $\mathrm{COH}$ retinas.

\section{Activation of ephrinB/EphB forward signaling promotes RGC apoptosis by up-regulating TNF-a}

We further demonstrated that activation of ephrinB/ EphB forward signaling in Müller cells induced by intravitreal injection of ephrinB1-Fc largely up-regulated the production of TNF- $\alpha$, thereby promoting RGC apoptosis, but without inducing Müller cell gliosis. To our best knowledges, this is the first report about the up-regulated TNF- $\alpha$ production by the activation of ephrinB/EphB forward signaling. It has been reported that TNF- $\alpha$ at a concentration of picogram level may induce neuronal cell death through the silencing of survival signals [64]. Indeed, soluble TNF- $\alpha$, by binding TNF receptor 1 , may mediate $\mathrm{RGC}$ apoptosis through modulating GluA2-lacking AMPA receptors in glaucomatous eyes [13]. In the present work we also demonstrated that RGC apoptosis in $\mathrm{COH}$ retinas was largely reduced when TNF- $\alpha$ was inhibited by XPro1595. All these results suggest that activation of ephrinB1/EphB1 forward signaling induced TNF- $\alpha$ production may play an important role in RGC apoptosis in glaucomatous eyes. We previously showed that EphB/ephrinB reverse signaling was also activated in $\mathrm{COH}$ retinas, which contributes to RGC apoptosis through decreasing the $\mathrm{Ca}^{2}$ ${ }^{+}$-impermeable GluA2-containing AMPA receptor expression in the membrane of RGCs [16]. It is of interest to note that in the $\mathrm{ONH}$ of spontaneous glaucomatous $\mathrm{DBA} / 2 \mathrm{~J}$ mice, the activation of $\mathrm{EphB/ephrinB}$ reverse signaling may contribute to the axon loss by causing an elevation of intracellular $\mathrm{Ca}^{2+}$ concentrations in RGC axons [17, 21], while ephrinB/EphB forward signaling may play a protective role for RGC axons, as suggested by the experiment showing that more serious degeneration of RGC axons was seen in experimental glaucomatous EphB2 ${ }^{-/-}$and EphB3 ${ }^{-/-}$mice [19]. Moreover, it was reported that in the rat forebrain traumatic injury activation of ephrinB3/EphB3 forward signaling attenuated neuronal death [63]. In this context it seems quite unique in the retinas with $\mathrm{COH}$ that the activation of both reverse and forward signaling of the ephrinB/EphB system, with EphB and ephrinB existing in a glial element and a neuronal element respectively, contributes to RGC apoptosis through different pathways.

It is known that production of TNF- $\alpha$ in glaucomatous retinas may be resulted by Müller cell gliosis [13, 41, 61, 62]. It has been shown that TNF- $\alpha$ released from the activated Müller cells may be mediated by p38-MAPK signaling pathway $[5,41,61]$. Indeed, we previously showed that this signaling pathway was also involved into mGluR I activation induced Müller cell gliosis [23]. In other words, TNF- $\alpha$ production from Müller cells in $\mathrm{COH}$ retinas could be due to ephrinB/EphB forward signaling activation and/or gliosis of Müller cells. A speculation about how these two mechanisms may work in $\mathrm{COH}$ retinas may be proposed as follows. Since the increase in EphB1 expression in Müller cells and ephrinB2 


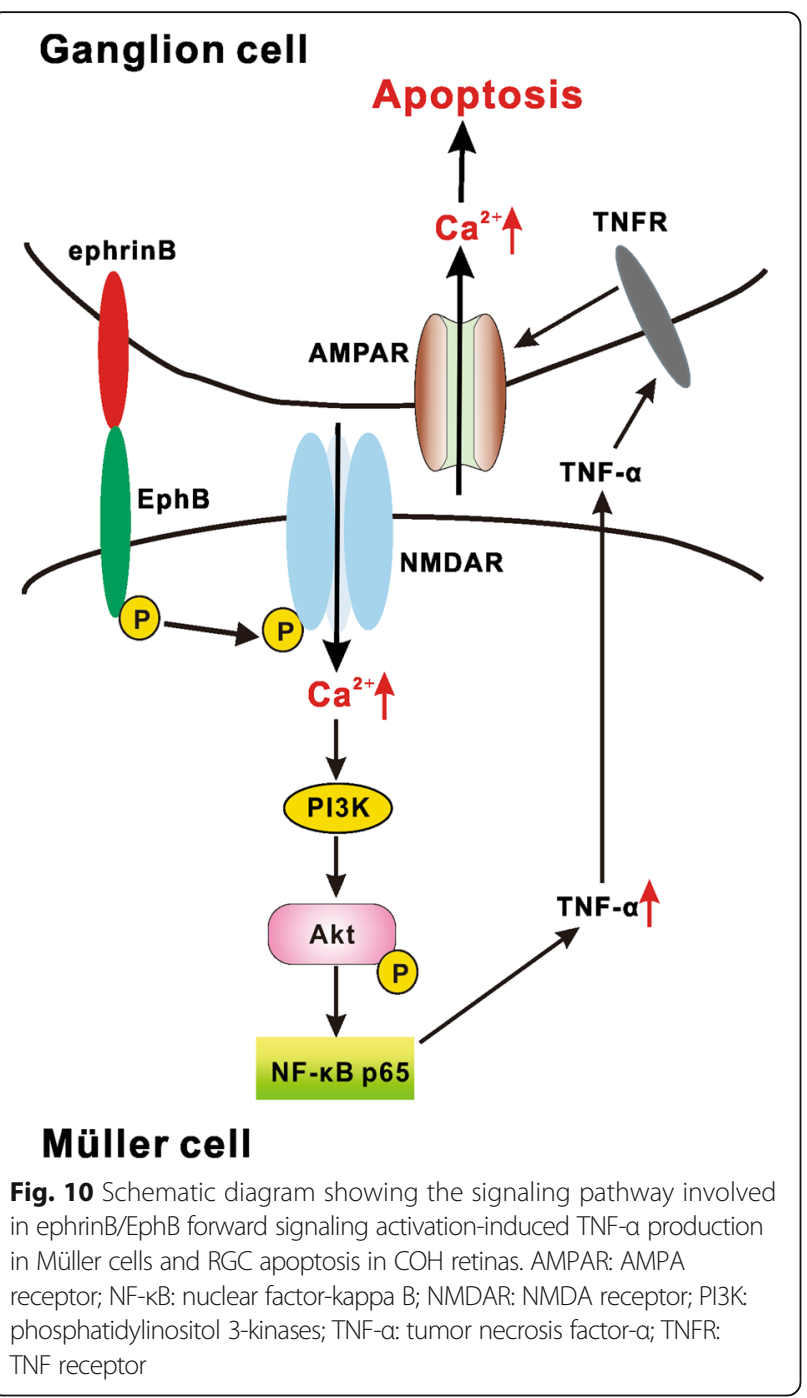

in RGCs was observed as early as 1 day (G1d) after IOP elevation [16], but a significant increase of GFAP expression was only observed on $\mathrm{G} 1 \mathrm{w}$ in $\mathrm{COH}$ retinas [33], it is reasonable to assume that at a very early phase of IOP elevation it may be the activation of ephrinB/EphB forward signaling that triggers the production of TNF- $\alpha$ from Müller cells. Steady IOP elevation could cause Müller cell gliosis, also resulting in the production of TNF- $\alpha$ and other inflammatory factors at a late phase. During this phase the glutamate concentration in the extracellular space is steadily increased, which could lead to more Müller cells to be reactivated and make ephrinB/EphB forward signaling activation stronger by stimulating mGluR I [33] and NMDA receptors (this work) respectively. In short, the two mechanisms may work in concert in the time domain to aggravate RGC damage. It seems likely that suppression of ephrinB/ EphB forward signaling may be regarded as a new strategy for ameliorating RGC apoptosis in glaucoma.
Involvement of NMDA receptors in ephrinB/EphB forward signaling activation induced TNF-a production in Müller cells

In glaucoma extracellular glutamate levels in the retina are elevated, which could be caused by reduced expression of glutamate transporters $[28,42,65]$. Since glutamate fails to increase obvious $\mathrm{Ca}^{2+}$ transition in Müller cells in rats and guinea pigs, it is generally thought that NMDA receptors are not involved in Müller cell gliosis $[7,45,46]$. Indeed, the activation of ephrinB/EphB forward signaling caused an increase in p-NR2B subuint expression in Müller cells, but did not change GFAP expression, a sign of Müller cell gliosis. While NMDA receptors do not contribute to Müller cell gliosis, our results strongly suggest that these receptors may be involved in the TNF- $\alpha$ production due to ephrinB/EphB forward signaling activation. This suggestion is supported by the result that the elevation of TNF- $\alpha$ mRNA and protein levels in Müller cells due to ephrinB1-Fc treatment was blocked by the selective NR2B antagonist RO25-6981 (Fig. 7). Previous studies have demonstrated that the effects of activation of ephrinB/EphB bi-directional signaling on neuronal functions were mediated through modulating NMDA receptors. For example, EphB may interact directly with NMDA receptors, thereby modulating central synaptic functions by changing NMDA receptor-dependent $\mathrm{Ca}^{2+}$ influx through increasing tyrosine phosphorylation of NR2B [8, $14,30,47,50,56,60]$. Additionally, intrathecal administration of ephrinB2-Fc to activate ephrinB/EphB forward signaling in adult rats could induce behavioral thermal hyperalgesia, which was mediated by NR2B tyrosine phosphorylation [56].

Overall, the PI3K/Akt/NF-kB signaling pathway, being responsible for the production of TNF- $\alpha$, is not much different from those mediating the actions on neurons following the activation of NR2B [4, 9, 36, 40, 52, 68]. However, there are two points that should be emphasized. First, prevention of the elevated expression of PI3K (Fig. 8) and the production of TNF- $\alpha$ (Fig. 7) following the activation of EphB receptors by RO25-6981 suggests a direct activation of PI3K/Akt in Müller cells by the $\mathrm{Ca}^{2+}$ influx through NR2B subunit, similar to that observed in cortical and hippocampal neurons $[4,9,36$, $52,68]$, but different from an indirect action of $\mathrm{Ca}^{2+}$, observed in rat cortical neurons, on PI3K/Akt through the adaptor protein APPL1, which was mediated by the synaptic NMDA receptor activity [67]. Second, it has been well established that activated Akt enables the NF- $\mathrm{kB}$ dimers to enter the nucleus and activating specific target genes that are responsible for inflammation and immune response $[15,26,31]$. This notion is supported by our result, showing that activated ephrinB/EphB forward signaling induced a significant increase in NF- $\mathrm{kB}$ p65 
expression in the nucleus component of Müller cells in mediation of p-Akt. This is also consistent with a previous work showing that NMDA treatment induced NF- $\kappa B$ activation in Müller cells, and then increased TNF- $\alpha$ production [40].

\section{Conclusions}

In the present work, we demonstrate that ephrinB/EphB forward signaling is activated in Müller cells in a chronic ocular hypertension model, which up-regulates TNF- $\alpha$ production via a distinct NR2B/PI3K/Akt/NF- $\mathrm{kB}$ signaling pathway and contributes to RGC apoptosis (Fig. 10), but without inducing Müller cell gliosis.

\begin{abstract}
Abbreviations
AMPA: a-amino-3-hydroxy-5-methyl-4-isoxazole-propionic acid; $\mathrm{COH}$ : Chronic ocular hypertension; ephB: Erythropoietin-producing hepatocyte receptor; GFAP: Glial fibrillary acidic protein; GluA2: Glutamate receptor subunit A2; NFKB: Nuclear factor-kappa B; NR2B: N-methyl-D-aspartate receptor subunit 2B; ONH: Optic nerve head; PI3K: Phosphatidylinositol 3-kinases; RGC: Retinal ganglion cell; TNF-a: Tumor necrosis factor-a; TUNEL: Terminal dUTP nick end labeling
\end{abstract}

\section{Acknowledgements}

We would like to thank Dr. David E. Szymkowski (Xencor) for the donation of XPro1595.

\section{Funding}

This work was supported by grants from the National Natural Science Foundation of China (81790642; 31671078; 81430007).

\section{Availability of data and materials}

All data generated or analyzed during this study are included in this published article.

\section{Authors' contributions}

$Z W$ and $Y M$ conceived and designed the experiments; STL, SMZ, XYL, FG, MLZ, $F L, Y M$ and $K Z$ performed the experiments; STL, XHS, XW, YM, XLY and ZW analyzed the data; STL, YM, XLY and ZW wrote the manuscript. All authors read and approved the final manuscript.

\section{Ethics approval and consent to participate}

All experiments described in this study were carried out in accordance with the National Institutes of Health $(\mathrm{NIH})$ guidelines for the Care and Use of Laboratory Animals, and were approved by the Institutes of Brain Science at Fudan University.

\section{Consent for publication}

Not applicable.

\section{Competing interests}

The authors declare that they have no competing interests.

\section{Publisher's Note}

Springer Nature remains neutral with regard to jurisdictional claims in published maps and institutional affiliations.

\section{Author details}

'Department of Neurology, Institutes of Brain Science, State Key Laboratory of Medical Neurobiology, Zhongshan Hospital, Fudan University, 131 Dongan Road, Shanghai 200032, China. ${ }^{2}$ Department of Ophthalmology at Eye \& ENT Hospital, Institutes of Brain Science, State Key Laboratory of Medical Neurobiology, Fudan University, Shanghai 200031, China.
Received: 18 September 2018 Accepted: 12 October 2018

Published online: 24 October 2018

\section{References}

1. Aoto J, Chen L (2007) Bidirectional ephrin/Eph signaling in synaptic functions. Brain Res 1184:72-80

2. Battaglia AA, Sehayek K, Grist J, McMahon SB, Gavazzi I (2003) EphB receptors and ephrin-B ligands regulate spinal sensory connectivity and modulate pain processing. Nat Neurosci 6:339-340

3. Brambilla R, Ashbaugh JJ, Magliozzi R, Dellarole A, Karmally S, Szymkowski DE et al (2011) Inhibition of soluble tumour necrosis factor is therapeutic in experimental autoimmune encephalomyelitis and promotes axon preservation and remyelination. Brain 134:2736-2754

4. Brennan-Minnella AM, Shen Y, El-Benna J, Swanson RA (2013) Phosphoinositide 3-kinase couples NMDA receptors to superoxide release in excitotoxic neuronal death. Cell Death Dis 4:e580

5. Bringmann A, landiev I, Pannicke T, Wurm A, Hollborn M, Wiedemann P et al (2009) Cellular signaling and factors involved in Müller cell gliosis: neuroprotective and detrimental effects. Prog Retin Eye Res 28:423-451

6. Bringmann A, Pannicke T, Grosche J, Francke M, Wiedemann P, Skatchkov SN et al (2006) Müller cells in the healthy and diseased retina. Prog Retin Eye Res 25:397-424

7. Bringmann A, Pannicke T, Weick M, Biedermann B, Uhlmann S, Kohen L et al (2002) Activation of P2Y receptors stimulates potassium and cation currents in acutely isolated human Müller (glial) cells. Glia 37:139-152

8. Calò L, Cinque C, Patanè M, Schillaci D, Battaglia G, Melchiorri D et al (2006) Interaction between ephrins/Eph receptors and excitatory amino acid receptors: possible relevance in the regulation of synaptic plasticity and in the pathophysiology of neuronal degeneration. J Neurochem 98:1-10

9. Chandler LJ, Sutton G, Dorairaj NR, Norwood D (2001) N-methyl D-aspartate receptor-mediated bidirectional control of extracellular signal-regulated kinase activity in cortical neuronal cultures. J Biol Chem 276:2627-2636

10. Chen J, Miao Y, Wang XH, Wang Z (2011) Elevation of p-NR2A(S1232) by $\mathrm{Cdk5/p35}$ contributes to retinal ganglion cell apoptosis in a rat experimental glaucoma model. Neurobiol Dis 43:455-464

11. Chen YQ, Zhong SM, Liu ST, Gao F, Li F, Zhao Y et al (2017) Neuroprotective effect of $5 \mathrm{a}$-androst-3 $3,5,6 \beta$-triol on retinal ganglion cells in a rat chronic ocular hypertension model. Neurosci Lett 660:90-95

12. Cibert-Goton V, Yuan G, Battaglia A, Fredriksson S, Henkemeyer M, Sears T et al (2013) Involvement of EphB1 receptors signalling in models of inflammatory and neuropathic pain. PLoS One 8:e53673

13. Cueva Vargas JL, Osswald IK, Unsain N, Aurousseau MR, Barker PA, Bowie D et al (2015) Soluble tumor necrosis factor alpha promotes retinal ganglion cell death in Glaucoma via calcium-permeable AMPA receptor activation. J Neurosci 35:12088-12102

14. Dalva MB, Takasu MA, Lin MZ, Shamah SM, Hu L, Gale NW et al (2000) EphB receptors interact with NMDA receptors and regulate excitatory synapse formation. Cell 103:945-956

15. Dan HC, Cooper MJ, Cogswell PC, Duncan JA, Ting JP, Baldwin AS (2008) Akt-dependent regulation of NF-KB is controlled by $\mathrm{mTOR}$ and raptor in association with IKK. Genes Dev 22:1490-1500

16. Dong LD, Gao F, Wang XH, Miao Y, Wang SY, Wu Y et al (2015) GluA2 trafficking is involved in apoptosis of retinal ganglion cells induced by activation of EphB/EphrinB reverse signaling in a rat chronic ocular hypertension model. J Neurosci 35:5409-5421

17. Du J, Tran T, Fu C, Sretavan DW (2007) Upregulation of EphB2 and ephrinB2 at the optic nerve head of DBA/2J glaucomatous mice coincides with axon loss. Invest Ophthalmol Vis Sci 48:5567-5581

18. Eastlake KBP, Angbohang A, Charteris DG, Khaw PT, Limb GA (2016) Mülle glia as an important source of cytokines and inflammatory factors present in the gliotic retina during proliferative vitreoretinopathy. Glia 64:495-506

19. Fu CT, Sretavan D (2012) Involvement of EphB/Ephrin-B signaling in axonal survival in mouse experimental glaucoma. Invest Ophthalmol Vis Sci 53:76-84

20. Fu CT, Tran T, Sretavan D (2010) Axonal/glial upregulation of EphB/ephrin-B signaling in mouse experimental ocular hypertension. Invest Ophthalmol Vis Sci 51:991-1001

21. Fu QL, Wu W, Wang H, Li X, Lee WW, So KF (2008) Up-regulated endogenous erythropoietin/erythropoietin receptor system and exogenous erythropoietin rescue retinal ganglion cells after chronic ocular hypertension. Cell Mol Neurobiol 28:317-329 
22. Gao F, Li F, Miao Y, Dong LD, Zhang SH, Wu J et al (2015) Group I metabotropic glutamate receptor agonist DHPG modulates Kir4.1 protein and mRNA in cultured rat retinal Müller cells. Neurosci Lett 588:12-17

23. Gao F, Li F, Miao Y, Xu LJ, Zhao Y, Li Q et al (2017) Involvement of the MEKERK/p38-CREB/c-fos signaling pathway in Kir channel inhibition-induced rat retinal Muller cell gliosis. Sci Rep 7:1480

24. Garcia TB, Pannicke T, Vogler S, Berk BA, Grosche A, Wiedemann P et al (2014) Nerve growth factor inhibits osmotic swelling of rat retinal glial (Müller) and bipolar cells by inducing glial cytokine release. J Neurochem 131:303-313

25. Ghosh A (2002) Neurobiology. Learning more about NMDA receptor regulation. Science 295:449-451

26. Gilmore TD (2006) Introduction to NF-kB: players, pathways, perspectives. Oncogene 25:6680-6684

27. Guan XH, Lu XF, Zhang HX, Wu JR, Yuan Y, Bao Q et al (2010) Phosphatidylinositol 3-kinase mediates pain behaviors induced by activation of peripheral ephrinBs/EphBs signaling in mice. Pharmacol Biochem Behav 95:315-324

28. Harada T, Harada C, Nakamura K, Quah HM, Okumura A, Namekata K et al (2007) The potential role of glutamate transporters in the pathogenesis of normal tension glaucoma. J Clin Invest 117:1763-1770

29. He S, Shao LR, Rittase WB, Bausch SB (2012) Increased Kv1 channel expression may contribute to decreased sIPSC frequency following chronic inhibition of NR2B-containing NMDAR. Neuropsychopharmacology 37:1338-1356

30. Henderson JT, Georgiou J, Jia Z, Robertson J, Elowe S, Roder JC et al (2001) The receptor tyrosine kinase EphB2 regulates NMDA-dependent synaptic function. Neuron 32:1041-1056

31. Hoesel B, Schmid JA (2013) The complexity of NF-KB signaling in inflammation and cancer. Mol Cancer 12:86

32. Hruska M, Dalva MB (2012) Ephrin regulation of synapse formation, function and plasticity. Mol Cell Neurosci 50:35-44

33. Ji M, Miao Y, Dong LD, Chen J, Mo XF, Jiang SX et al (2012) Group I mGluRmediated inhibition of Kir channels contributes to retinal Müller cell gliosis in a rat chronic ocular hypertension model. J Neurosci 32:12744-12755

34. Joyal JL, Burks DJ, Pons S, Matter WF, Vlahos CJ, White MF et al (1997) Calmodulin activates phosphatidylinositol 3-kinase. J Bio Chem 272:2818328186

35. Kania A, Klein R (2016) Mechanisms of ephrin-Eph signalling in development, physiology and disease. Nat Rev Mol Cell Biol 17:240-256

36. Kim Jl, Lee HR, Sim SE, Baek J, Yu NK, Choi JH et al (2011) PI3Kgamma is required for NMDA receptor-dependent long-term depression and behavioral flexibility. Nat Neurosci 14:1447-1454

37. Kullander K, Klein R (2002) Mechanisms and functions of Eph and ephrin signalling. Nat Rev Mol Cell Biol 3:475-486

38. Lai KO, Ip NY (2009) Synapse development and plasticity: roles of ephrin/ Eph receptor signaling. Curr Opin Neurobiol 19:275-283

39. Lamas M, Fau L-RI, Lopez-Colome AM (2005) Cell-specific expression of Nmethyl-D-aspartate receptor subunits in Muller glia and neurons from the chick retina. Invest Ophthalmol Vis Sci 46:3570-3577

40. Lebrun-Julien F, Duplan L, Pernet V, Osswald I, Sapieha P, Bourgeois P et al (2009) Excitotoxic death of retinal neurons in vivo occurs via a non-cellautonomous mechanism. J Neurosci 29:5536-5545

41. Livne-Bar I, Lam S, Chan D, Guo X, Askar I, Nahirnyj A et al (2016) Pharmacologic inhibition of reactive gliosis blocks TNF-alpha-mediated neuronal apoptosis. Cell Death Dis 7:e2386

42. Martin KR, Levkovitch-Verbin H, Valenta D, Baumrind L, Pease ME, Quigley HA (2002) Retinal glutamate transporter changes in experimental glaucoma and after optic nerve transection in the rat. Invest Ophthalmol Vis Sci 43: 2236-2243

43. Miao Y, Dong LD, Chen J, Hu XC, Yang XL, Wang Z (2012) Involvement of calpain/p35-p25/Cdk5/NMDAR signaling pathway in glutamate-induced neurotoxicity in cultured rat retinal neurons. PLoS One 7:e42318

44. Murphy PG, Grondin J, Altares M, Richardson PM (1995) Induction of interleukin-6 in axotomized sensory neurons. J Neurosci 15:5130-5138

45. Newman EA (2005) Calcium increases in retinal glial cells evoked by lightinduced neuronal activity. J Neurosci 25:5502-5510

46. Newman EA, Zahs KR (1997) Calcium waves in retinal glial cells. Science 275: 844-847

47. Nolt MJ, Lin Y, Hruska M, Murphy J, Sheffler-Colins SI, Kayser MS et al (2011) EphB controls NMDA receptor function and synaptic targeting in a subunitspecific manner. J Neurosci 31:5353-5364
48. Palmer A, Klein R (2003) Multiple roles of ephrins in morphogenesis, neuronal networking, and brain function. Genes Dev 17:1429-1450

49. Park I, Lee HS (2015) EphB/ephrinB signaling in cell adhesion and migration. Mol Cells 38:14-19

50. Pasquale EB (2008) Eph-ephrin bidirectional signaling in physiology and disease. Cell 133:38-52

51. Pasquale EB (2010) Eph receptors and ephrins in cancer: bidirectional signalling and beyond. Nat Rev Cancer 10:165-180

52. Perkinton MS, Ip JK, Wood GL, Crossthwaite AJ, Williams RJ (2002) Phosphatidylinositol 3-kinase is a central mediator of NMDA receptor signalling to MAP kinase (Erk12), AktPKB and CREB in striatal neurones. J Neurochem 80:239-254

53. Puro DG, Yuan JP, Sucher NJ (1996) Activation of NMDA receptor-channels in human retinal Muller glial cells inhibits inward-rectifying potassium currents. Vis Neurosci 13:319-326

54. Rajasekar N, Nath C, Hanif K, Shukla R (2016) Inhibitory effect of Memantine on Streptozotocin-induced insulin receptor dysfunction, Neuroinflammation, Amyloidogenesis, and neurotrophic factor decline in astrocytes. Mol Neurobiol 53:6730-6744

55. Schmidt JF, Agapova OA, Yang P, Kaufman PL, Hernandez MR (2007) Expression of ephrinB1 and its receptor in glaucomatous optic neuropathy. Br J Ophthalmol 91:1219-1224

56. Slack S, Battaglia A, Cibert-Goton V, Gavazzi I (2008) EphrinB2 induces tyrosine phosphorylation of NR2B via Src-family kinases during inflammatory hyperalgesia. Neuroscience 156:175-183

57. Srivastava N, Robichaux MA, Chenaux G, Henkemeyer M, Cowan CW (2013) EphB2 receptor forward signaling controls cortical growth cone collapse via Nck and Pak. Mol Cell Neurosci 52:106-116

58. Steinle JJ, Meininger CJ, Forough R, Wu G, Wu MH, Granger HJ (2002) EphB4 receptor signaling mediates endothelial cell migration and proliferation via the phosphatidylinositol 3-kinase pathway. J Biol Chem 277 43830-43835

59. Su H, Zhang W, Guo J, Guo A, Yuan Q, Wu W (2009) Neural progenitor cells enhance the survival and axonal regeneration of injured motoneurons after transplantation into the avulsed ventral horn of adult rats. J Neurotrauma 26:67-80

60. Takasu MA, Dalva MB, Zigmond RE, Greenberg ME (2002) Modulation of NMDA receptor-dependent calcium influx and gene expression through EphB receptors. Science 295:491-495

61. Tezel G, Li LY, Patil RV, Wax MB (2001) TNF-alpha and TNF-alpha receptor-1 in the retina of normal and glaucomatous eyes. Invest Ophthalmol Vis Sci 42:1787-1794

62. Tezel G, Wax MB (2003) Glial modulation of retinal ganglion cell death in glaucoma. J Glaucoma 12:63-68

63. Theus MH, Ricard J, Glass SJ, Travieso LG, Liebl DJ (2014) EphrinB3 blocks EphB3 dependence receptor functions to prevent cell death following traumatic brain injury. Cell Death Dis 5:e1207

64. Venters HD, Dantzer R, Kelley KW (2000) A new concept in neurodegeneration: TNFalpha is a silencer of survival signals. Trends Neurosci 23:175-180

65. Vorwerk CK, Naskar R, Schuettauf F, Quinto K, Zurakowski D, Gochenauer G et al (2000) Depression of retinal glutamate transporter function leads to elevated intravitreal glutamate levels and ganglion cell death. Invest Ophthalmol Vis Sci 41:3615-3621

66. Walker PA, Harting MT, Jimenez F, Shah SK, Pati S, Dash PK et al (2010) Direct intrathecal implantation of mesenchymal stromal cells leads to enhanced neuroprotection via an NFkappaB-mediated increase in interleukin-6 production. Stem Cells Dev 19:867-876

67. Wang YB, Wang JJ, Wang SH, Liu SS, Cao JY, Li XM et al (2012) Adaptor protein APPL1 couples synaptic NMDA receptor with neuronal prosurvival phosphatidylinositol 3-kinase/Akt pathway. J Neurosci 32:11919-11929

68. Waxman EA, Lynch DR (2005) N-methyl-D-aspartate receptor subtype mediated bidirectional control of p38 mitogen-activated protein kinase. J Biol Chem 280:29322-29333

69. Yu LN, Zhou XL, Yu J, Huang H, Jiang LS, Zhang FJ et al (2012) PI3K contributed to modulation of spinal nociceptive information related to ephrinBs/EphBs. PLoS One 7:e40930

70. Zhao WJ, Zhang M, Miao Y, Yang XL, Wang Z (2010) Melatonin potentiates glycine currents through a PLC/PKC signalling pathway in rat retinal ganglion cells. J Physiol 588:2605-2619 